\title{
Impact of the level of bank liquidity on the relationship between concentration and bank efficiency: the case of the WAEMU
}

\author{
Abdoulaye Ndiaye \\ Université Gaston Berger de Saint-Louis-Sénégal
}

\begin{abstract}
In this article, we investigate the impact of bank liquidity level on the relationship between bank concentration and efficiency using a panel dataset of 60 banks across 7 WAEMU countries over the period 20052016. Our empirical methodology is based on the 2SLS IV estimator and non-linear analysis. Our results show that the concentration of the banking sector and the bank liquidity are negatively correlated with cost efficiency in the WAEMU. This is consistent with the Quiet Life Hypothesis which established that concentrated market incites suboptimal behaviors damaging to the banking profitability. However, the effects of concentration on cost efficiency are reduced for banks with lower levels of excess liquidity. This result shows that the holding of excess liquidity reinforces the effects of the Quiet Life Hypothesis.
\end{abstract}

Keywords: Banking efficiency, concentration, excess liquidity, WAEMU.

\section{Introduction}

The financial liberalization policies of the 1990s have brought about profound changes in the financial systems of Sub-Saharan African (SSA) countries over the past 24 years. Within the West African Economic and Monetary Union (WAEMU), these changes have taken various forms: notably, i) the gradual cleaning up of the financial sector, ii) the restoration of bank liquidity and profitability, and iii) the holding of large stocks of excess reserves at the Central Bank of West African States - BCEAO (e.g., \$1545.6 million on average over the period 1995-2015). These changes have also affected the structure of the WAEMU banking sector. Indeed, the banking sector has been marked in the last decade by the race for optimal size, the emergence of large groups and new players.

Indeed, the number of banks operating in the Union is constantly increasing and doubling (143 banks in 2018, compared to 72 banks in 2003, an increase of 98.6\%). However, the banking sector is highly concentrated, because a few banks hold a significant share of deposits, credits and customers. For example, in 2014, the five largest banking groups concentrated 53.7 per cent of total balance sheets compared to 50.7 per cent in 2007 (BCEAO, 2007 and 2014). In 2018, this concentration was confirmed again with the seven largest banking groups in WAEMU holding $60 \%$ of total assets (BCEAO, 2019). The sector is dominated by seven (7) banking groups which hold $50.4 \%$ of banking 
assets, $34.9 \%$ of the branch network, $41.4 \%$ of ATMs, $54.0 \%$ of bank accounts and employ $47.9 \%$ of staff (BCEAO, 2019). The level of concentration, size, and banking group dimension illustrates the oligopolistic nature of WAEMU's banking system.

The link between liquidity level, bank concentration and efficiency in the WAEMU has remained, at best, at the stage of theoretical argument (Nubukpo, 2007b and Joseph, 2002). At present, empirical investigations have focused on the limit on the link between bank concentration and bank performance (see, Ndiaye, 2018, Ouédraogo, 2012; Léon, 2012) but not in the sense that this link could be affected by the level of bank liquidity. The objective of this paper is to assess the impact of the level of bank liquidity on the relationship between bank concentration and efficiency in the WAEMU. Within an analytical framework based on the Structure-Behavior-Performance (SBP) theory (Bain, 1956) which defines a causality from market structure to efficiency, we test the Quiet Life Hypothesis (QLH) by taking into account the effect of the level of liquidity. This theory, which states that a weakly competitive banking sector encourages sub-optimal behaviour that is detrimental to bank profitability, has been the subject of much controversy in the economics literature. For example, QLH is confirmed by (Turk Ariss, 2010), (Delis and Tsionas, 2009) and (Boyd and De Nicolo, 2005), while (Presbitero and Zazzaro, 2011), (Degryse and Ongena, 2007) and (Dell'Ariccia and Marquez, 2004), reject it.

In the context of SSA economies, no study, to our knowledge, has attempted to analyze the link between market structure and efficiency to the level of bank liquidity following the QLH paradigm. Recently, (Eggoh and al., 2021) confirms the QLH in the UEMOA without taking into account the level of excess liquidity. The study we propose here intends to extend that of (Eggoh and al., 2021) by empirically testing the QLH to the level of bank liquidity in a monetary union. To achieve this objective, we adopt a "two-step" approach consisting in measuring first, the type of market structure of the banking sectors of the WAEMU countries and the cost efficiency levels of banks. We then conduct a regression analysis. To assess the market structure of banks, we use a structural indicator (the Herfindahl-Hirschman concentration index) and a non-structural indicator (the Lerner index). The measurement of cost efficiency scores is done by combining the Data Envelopment Analysis (DEA) and the Stochastic Frontier Analysis (SFA). To test the QLH and the impact of the level of bank liquidity on the relationship between market concentration and efficiency, we first perform a panel regression using the instrumental variables method (2SLS IV), followed by a non-linear regression analysis.

The second part of the article is devoted to the review of the literature. The third part presents the methodology and data. The fourth part presents and analyses the results.

\section{Literature review}

At the theoretical level, two approaches attempt to explain the effects of market structure on efficiency: the SCP approach and the QLH theory. The SCP model, originally developed by (Bain, 1956), predicts firm behaviour determined by the structure of the industry, the key factors of which are the number, size and concentration of suppliers (Dietsch, 1992). According to this model, concentration reflects a situation of non-competition (or very weak competition) which induces the same behaviours and results expected from monopoly or oligopoly markets. In a situation of limited competition (high concentration), some firms can extract monopoly rents while maintaining socially suboptimal levels of production and pricing, but compatible with maximum levels of profitability. 
The QLH theory, developed by (Hicks, 1935), assumes that managers will not be-have in a profitmaximizing way in a situation of limited competition. Without competitive pressure, managers have an incentive to reduce their efforts (Selten, 1986) and/or divert some resources to other objectives (Hermalin, 1992). Thus, according to the QLH, a concentrated market gives firms monopoly power, which encourages sub-optimal behaviour that is harmful to their profitability.

A positive relationship between concentration and performance is assumed by the SCP model, while the QLH defends the negative relationship.

The first empirical work analyzing the role of market structure on banking efficiency was developed in the United States to support the SCP model (Gilbert and Zaretsky, 2003; Berger and Hannan, 1998; Hannan, 1991; Gilbert, 1984). This early work showed that banks can improve their performance when the industry is concentrated. Other studies that have attempted to characterize the determinants of banking efficiency in some developed countries have simply introduced a measure of concentration into their model. The conclusions of these studies are very mixed. Some studies conclude a positive relationship between banking market concentration and cost efficiency (Maudos and De Guevara 2007; Fries and Taci, 2005; Grigorian and Manole, 2002), for others, the link is rather negative (Lapteacru and Nys, 2011; Dietsch and Lozano-Vivas, 2000).

Empirical studies of the PCS paradigm in the case of developing countries are scarce and the results are very inconclusive. The empirical analysis of the relationship between profitability and the share of assets controlled by the three largest firms proposed by (Demirguç-Kunt and Huizinga, 1999) is certainly the most important. It covers a sample of 80 developed and developing countries over the period 1989-1995. They show that the bank concentration ratio is positively related to bank profitability. Using a sample of 55 developing countries and the Lerner index as a proxy for market power, (Amidu, 2011) finds a positive relationship between market power and bank profitability. (Flamini et al., 2009) reject the SCP hypothesis in a study of 41 banking systems in African countries. (Okeahalam, 2002a, b, 1998) tests the PCS hypothesis in a subset of Southern African economies. (Chirwa, 2003) reaches the same conclusion for Malawi, while in Uganda, Nigeria and Kenya, the results do not support the PCS hypothesis.

Works that have attempted to empirically test the HLQ hypothesis generally yield mixed results in both developed and developing countries. For example, (Delis and Tsionas, 2009) and (Boyd and De Nicolo, 2005) confirm the HLQ, while (Williams, 2012) and (Koetter et al., 2012) reject it.

Overall, the contradictory results on the link between market concentration and efficiency could be explained by the specific features of the study areas, which are often characterised by different banking structures, but also by differences in the choice of market concentration indicators (structural or non-structural indicators).

In SSA, no study, to our knowledge, has attempted to analyze the link between market structure and efficiency to excess bank liquidity following the QLH paradigm. The few works on the determinants of bank efficiency have simply introduced a measure of concentration in their model (e.g. (Kablan, 2009a, b); (Flamini et al., 2009), (Ndiaye, 2008); (Kirkpatrick et al., 2008), etc.) to capture the effect of concentration on efficiency) to capture the effect of market concentration, but not a direct analysis of the impact of excess bank liquidity on the relationship between market concentration and efficiency. In the UEMOA context, (Ouédraogo, 2012) studied, following the SCP paradigm, the impact of bank concentration on bank profitability on the one hand, and on bank financial deepening on the other. Using four different measures of banking concentration (the number of banks, CR3 and CR2 ratios as 
well as the HHI index), he shows that banking concentration positively affects banking financial profitability (ROE) and economic return (ROA) and that it limits banking financial deepening in the Union. More recently, (Eggoh and al., 2021) confirms the QLH in the WAEMU but ignores the level of excess liquidity. The study we propose here intends to extend that of (Eggoh and al., 2021) by testing the QLH to the level of banking liquidity in a monetary union.

\section{Methodology and data}

\subsection{Concentration measurements}

Many studies associate the level of market power with the level of market concentration, expressed by the Herfindahl-Hirschmann Index (HHI). It is calculated as the sum of the squares of the market shares (ms) of banks in country $i$ at date $t$ according to the following formula:

$H H I_{i t}=\sum_{i=1}^{m} m S_{i t}^{2}$

The HHI index is a more comprehensive and accurate measure of concentration. A high value reflects a highly concentrated market and a lower level of competition, as banks are expected to have more market power. Also, if competition is perfect, HHI tends to 0 , while a monopoly or oligopoly structure results in an HHI above 1000. However, the HHI index has many shortcomings: for example, it does not take into account the average size of banks, the complexity of the banking sector in terms of product and business varieties, the elasticity of demand, among others (Ryan et al., 2014). Therefore, we use an alternative measure of market power, the Lerner index, which directly captures the competitive banking environment. It has the advantage of capturing the market power of each bank. Conventionally, Lerner's indicator of market power is the difference between the price set by bank $i$ at time $\mathrm{t}$ (pit) and the marginal cost of producing that good $\mathrm{Cm}$ it relative to price:

$L_{-} i t=\left(P_{-} i t-\llbracket c m \rrbracket \_i t\right) / P_{-} i t$

The price $P_{-} i t$ is constructed using the approximation given by average income, i.e. by relating annual income $\left(\mathrm{R}_{\mathrm{it}}\right)$ to total assets (AT ): $P_{-} i t=\mathrm{RM}_{\mathrm{it}}=\mathrm{R}$ it $/ \mathrm{AT}_{\mathrm{it}}$. The index thus formulated takes values between 1 and 0 . It is 0 in the pure and perfect competition since the prices of banking products and services are equal to marginal cost. Conversely, the existence of market power (concentration) on the part of banks makes it tend towards 1 . In the end, the Lerner index decreases as the degree of bank competition (bank concentration) increases (decreases).

Estimating the price and marginal cost of the bank under consideration represents the major difficulty related to the use of this market power indicator. To this end, we adopt the conventional approach proposed by the literature (Lapteacru and Nys, 2011; Turk Ariss, 2010, etc). Thus, assuming that the flow of banking products and services is proportional to the size of total assets (TA) of banks, we consider total assets as the only indicator of banking activity.

Following (Eggoh and al., 2021), (Dannon et al., 2019), (Lapteacru and Nys, 2011) and (Turk Ariss, 2010), we estimate the cost function from a translog function taking the following form: 


$$
\begin{gathered}
\ln C_{i t}=\theta_{0}+\sum_{j=1}^{3} \theta_{j} \ln w_{j, i t}+\theta_{4} \ln Q_{k, i t}+\frac{1}{2} \sum_{k=1}^{3} \sum_{l=1}^{3} \phi_{k l} \ln w_{k, i t} \ln w_{l, i t}++\frac{1}{2} \rho_{1}\left(\ln Q_{k, i t}\right)^{2} \\
+\sum_{k=1}^{3} \tau_{k} \ln w_{k, i t} \ln Q_{k, i t}+\ln u_{i t}+\ln v_{i t}
\end{gathered}
$$

Where $\mathrm{C}_{\mathrm{it}}$ is the cost of bank $\mathrm{i}$ at date $\mathrm{t}$, the price of resources attracted, $\mathrm{w}_{1}$ is measured as the ratio of interest expense (interest paid) to depositors to the amount of deposits, the price of labour, $\mathrm{w}_{2}$ is obtained by dividing labour expense by total assets ${ }^{1}$; and finally, the price of capital, $\mathrm{w}_{3}$, is estimated as the sum of depreciation and amortization expenses and charges on leasing and similar transactions, all expressed as a percentage of total assets.

After regressing this function with the symmetry and homogeneity conditions for the price coefficients ${ }^{2}$ imposed on it, the marginal cost is obtained by deriving the total costs to the total assets (Q). Let as follows:

$$
c m_{i t}=\frac{\partial C_{i t}}{\partial A T_{i t}}=\left[\theta_{4}+\rho_{1} \ln A T_{i t}+\sum_{k=1}^{3} \tau_{k} \ln w_{k, i t}\right] \frac{C_{i t}}{A T_{i t}}
$$

\subsection{Measures of efficiency}

For comparison purposes, we will determine the level of efficiency using two techniques: Data Envelopment Analysis (DEA) and Stochastic Frontier Analysis (SFA). Their advantages are not exclusive, and the results allow us to refine the conclusions.

\section{Data Envelopment Analysis}

Being a non-parametric technique, it does not require the precise writing of a cost function. The results are obtained following mathematical calculations related to linear programming and not following an econometric regression. The main limitation of this method is that it does not consider the existence of the error term in the series by excluding it as a factor that can affect the quantities of goods produced. Therefore, if the cost function does not contain all the determining factors, then the results may be overestimated. The brief description of the DEA method is based on the study by (Charnes et al., 1978). Let us assume that there are $\mathrm{K}$ factors of production and $\mathrm{M}$ goods for each bank $\mathrm{i}(\mathrm{i}=1, \ldots, \mathrm{N})$. Let us denote by $x i$ and $y$, respectively, the vectors of the factors of production used by bank $\mathrm{i}$ and the goods offered by this same bank. Let us denote by $\mathrm{K} \times \mathrm{N}$ the matrix of production factors $\mathrm{X}$ and by $\mathrm{M} \times \mathrm{N}$ the matrix of goods $\mathrm{Y}$. To measure the cost efficiency of each bank, we calculate the ratio of the quantities produced to the quantities of the factors of production expressed by $u^{\prime} y i / v^{\prime} x i$, where $u$ is the $M \times 1$ vector of weights of the quantities offered and $v$ is the vector of weights of the factors of production. The optimal weights are determined by solving the following mathematical programming problem:

\footnotetext{
${ }^{1}$ Since the number of employees is not available. we use instead of the total assets as a proxy.

${ }^{2}$ By imposing $\sum \theta j=1 ; \sum \varphi k=0$. This condition ensures that only a change affecting the input price ratios can affect the allocation of factors of production during the cost minimization process.
} 
$\max \left(u^{\prime} y i / v^{\prime} x i\right)$

$u, v$

Under conditions (s.c.) $u^{\prime} y j / v ' x j \leq 1, j=1, ., N$ and $u, v \geq 0$.

However, this formulation assumes the existence of an infinite number of solutions, which requires the constraint

$v^{\prime} x \mathrm{i}=1$ :

$\max \left(\mu^{\prime} y\right)$

$\mu, \rho$

s.c. $\rho^{\prime} x i=1, \mu^{\prime} y i-\rho^{\prime} x j \leq 0, j=1, ., N$ and $\mu, \rho \geq 0$,

Where the notations $u$ and $v$ have been, respectively changed to $\mu$ and $\rho$ to reflect the transformation. Using duality in linear programming, an equivalent form of the problem can be written as follows:

$\min \theta$

$\theta \lambda$

s.c. $-y i+Y \lambda \geq 0, \theta x i-X \lambda \geq 0, N I^{\prime} \lambda=1, \lambda \geq 0$

Where $\theta$ is a scalar, $\lambda$ is a vector of $\mathrm{Nx} 1$ constants and $\mathrm{I}$ is the identity matrix. The resulting value of $\theta$ represents the efficiency score of bank $\mathrm{i}$ and takes values between 0 and 1 . The problem must be solved $\mathrm{N}$ times, once for each bank.

\section{Stochastic Frontier Analysis}

Conceptually, the DEA and SFA methods are similar. A cost-efficiency frontier must be determined as a result of a cost function on which the most efficient bank lies, and the efficiency of the other banks is determined to this. However, the SFA approach distinguishes the effects of noise (measurement errors) from the effects of inefficiency and thus takes into account the presence of exogenous shocks. In the SFA approach, the cost inefficiency measures the difference between the bank's cost and the cost of producing the same quantity of goods under the same conditions. It is based on the regression of the same cost function (3), where it is assumed that where $\varepsilon_{i t}=v_{i t}+u_{i t} v_{i t}$ is independent and identically distributed and follows a normal distribution and $u_{i t}$ which takes only nonnegative values following a semi-normal distribution below $N\left(\mu, \sigma^{2}\right), \mu>0$. The latter component participates in the construction of the cost frontier $\left(u_{i t}=0\right.$ corresponding to the optimal cost function) of each bank $i$ at date $t$ and, thereby, in the estimation of the cost efficiency score. Similar to (Dannon et al., 2019), the estimation of the cost function relies on the intermediation approach as banks collect deposits and other liabilities and convert them into interest-bearing assets such as investments and loans. In the end, we calculate the cost efficiency using the formula of (Jondrow et al., 1982) i.e.:

$$
E F F_{i t}=E\left(\exp \left(-u_{i t}\right)\right)
$$

\subsection{Empirical model}

After analyzing the concentration indicators, we test the HLQ by considering the level of bank liquidity. We use the cross-effects technique as proposed in the literature (e.g. Nguyen and Boateng, 2013; Ouédraogo, 2011; Gunji and Yuan, 2010, etc.). This technique consists of doing the combination of two variables $(\mathrm{X} * \mathrm{Z})$, to measure the impact of $\mathrm{X}$ on the linkage between $\mathrm{Z}$ and $\mathrm{Y}$ with 
$\mathrm{Y}$ as the endogenous variable. (Nguyen and Boateng, 2013) used it to assess the impact of excess bank liquidity on the credit channel in China by combining the excess liquidity indicator with the policy interest rate.

We first assess the direct effect of the two variables of interest (concentration and bank liquidity) on the cost efficiency of banks, taking into account the control variables specific to the banking activity and the macroeconomic environment. Let us consider the following linear model:

$$
\begin{gathered}
E F F_{i t}=\alpha_{i}+\alpha_{1} \text { Lerner }_{i t}+\alpha_{2} \text { EL }_{i t}+\alpha_{3} \text { Cap }_{i t}+\alpha_{4} \text { Dep }_{i t}+\alpha_{5} \text { Cred }_{i t}+\alpha_{6} \text { Taille }_{i t} \\
+\alpha_{7} \text { Growth }_{i t}+\alpha_{8} I N F_{i t}+\varepsilon_{i t}
\end{gathered}
$$

Where $\mathrm{EL}_{\text {it }}$ represents the excess bank liquidity indicator of bank $\mathrm{i}$ at date $\mathrm{t}$. It is measured by the ratio of free reserves (Reserves - required reserves) to total deposits. The Lerner ${ }_{i t}$ variable represents the bank concentration indicator (Lerner index or HHI). In addition to the variables of interest (concentration and bank liquidity level), we retain several control variables regarding the empirical literature (Dannon et al., 2019, Lapteacru and Nys, 2011; Grigorian and Manole, 2002, etc.). By adopting some of these variables in the context of the WAEMU banking system, we retain the following control variables (Eggoh and al., 2021): Dep and Cred which represent respectively the ratios of bank deposits and outstanding credit to total assets, Size, is measured by the market share of each bank i on its national market, bank capitalization (Cap), the GDP growth rate (Growth) and finally inflation (INF).

Finally, we estimate the role of the cross effect, i.e. the impact of the level of liquidity on the relationship between market concentration and efficiency. In a growing financial system such as the WAEMU, the relationship between market concentration and bank efficiency may itself be affected by changes in banking characteristics. Since excess liquidity is itself a factor of inefficiency (Khemraj, 2008), one would expect that banks with less excess liquidity would only improve their efficiency level when the market is concentrated. In this case, the observed effects of market concentration on efficiency decrease. Consider the following non-linear model:

$$
\begin{aligned}
& \text { EFF }_{i t}=\alpha_{i}+\alpha_{1} \text { Lerner }_{i t}+\alpha_{2}\left(\text { Lerner }_{i t} \times \text { Excess } 50_{i t}\right)+\alpha_{3} \text { Cap }_{i t}+\alpha_{4} \text { Dep }_{i t}+\alpha_{5} \text { Cred }_{i t}+\alpha_{6} \text { Taille }_{i t}+ \\
& \alpha_{7} \text { Growth }_{i t}+\alpha_{8} I N F_{i t}+\varepsilon_{i t}
\end{aligned}
$$

Where the variable (Lerner ${ }_{i t} \times$ Excess $50_{\text {it }}$ ) captures the cross effect. The Excess50 variable is a dummy variable describing the lowest levels of excess liquidity (50 percentile of the data) of the excess bank liquidity (EL) variable. Thus, when the parameters $\alpha 1$ and $\alpha 2$ have the same sign, we will say that the effects of market concentration on efficiency strengthen simultaneously for banks with less excess liquidity. On the other hand, if $\alpha$ 1and $\alpha$ 2have opposite signs, we conclude that the effects of market concentration on efficiency decrease for these same banks.

For the estimation of equations 9 and 10, we use the instrumental variable estimation technique 2SLS VI. This method allows us to take into account the problems related to the strong endogeneity between market structure and efficiency. Indeed, the SCP theory suggests that efficiency depends on market structure, but the theory of efficiency of structure (Peltzman, 1977 and Demsetz, 1973) claims the opposite relationship. There is therefore a risk of endogeneity. We use the one-period lagged 
variable of the market structure indicator as an instrument. This method has been used in recent studies by (Eggoh and al., 2021) and (Dannon et al., 2019).

\subsection{Data and descriptive statistics}

The study covers a sample of 60 banks $^{3}$ in seven WAEMU countries (Benin, Burkina Faso, Côte d'Ivoire, Mali, Niger, Senegal, and Togo) over the period 2005-2016. This choice is justified by the availability of data. The data used are from the BCEAO.

\section{Excess liquidity in the WAEMU banking sector}

The excess liquidity in the banking system is evidenced by the size of the free reserves held by banks. Figure 1 shows that these reserves have increased continuously in the banking system from 1995 to 2015 , except for the period from 2004 to 2006 . On average, they represent $\$ 1545.064$ million over the 1995-2015 period, rising from CFAF \$303.9 million in 1995 to $\$ 4187.1$ million in 2015. The required reserves also follow the same trend although remaining below the free reserves, but mark a fall from 2011. Moreover, the gap between free reserves and required reserves is considerable, especially since the required reserve rate is set by the BCEAO at a high average rate (7\% in 2010). On average, over the period 1995-2015, this gap was $\$ 1006$ million. The consequence of this dynamic in bank reserves is the weakness of the refinancing provided by the BCEAO. Indeed, the amount of refinancing granted to banks by the Central Bank fell from $\$ 284.2$ million in 1995 to $\$ 42.9$ million in 2006, i.e., a decline of $14.56 \%$ on average each year. It then grows to $\$ 4013.6$ million in 2015 , representing nearly $96 \%$ of free reserves of banks and $12.1 \%$ of domestic credit. The upward trend in the level of refinancing of banks from 2007 could be explained by the willingness of the Central Bank to support banks to supplement their resilience during the crisis of 2007-2008. Meanwhile, the banks had a significant level of autonomous reserves ( $\$ 1015.5$ on average in the period 2007-2015) that certainly could absorb some of the shocks. This means that the banks exited with a net increase in their liquidity. This excess liquidity is still evident more recently, accounting for 38\% of deposits in 2017 even though the trend is downward.

Figure 1. Evolution of free reserves, required reserves and refinancing of the Centrale Bank over the period 1995-2015 (in millions of CFA)

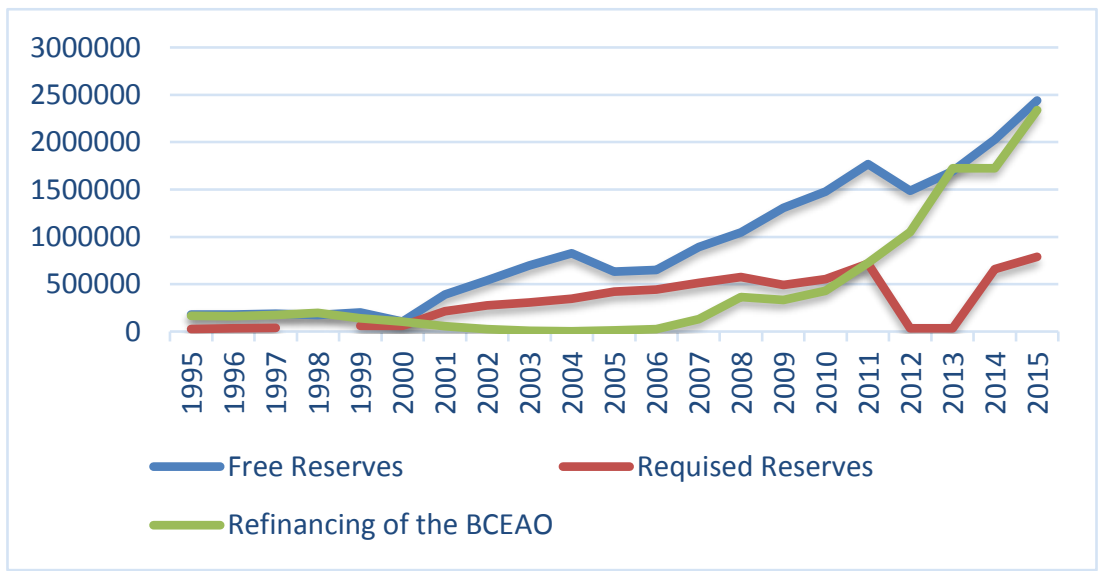

Source: Author's construction from BCEAO data.

\footnotetext{
${ }^{3}$ This number does not include banks that were created after 2003 and those that ceased to exist after that period.
} 
The level of excess liquidity of banks is disparate by countries in the period 2000-2016. It varies between $11.3 \%$ and $20.2 \%$ of deposits, on average. Côte d'Ivoire has the lowest level and Niger the highest. It now recognized that the extent of excess bank liquidity in WAEMU has been aggravated by the upheavals resulting from the 1990 financial reforms.

Figure 2. Average bank excess liquidity ratios by country

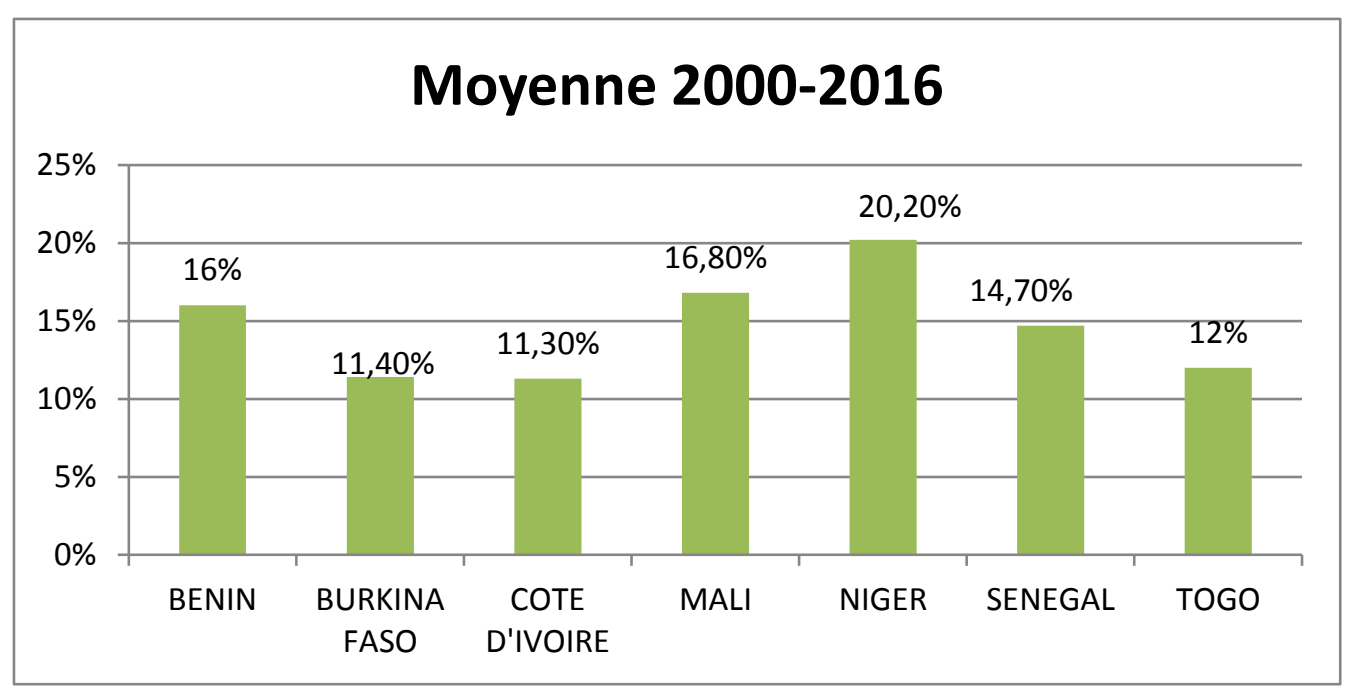

Source: Author's construction from BCEAO data.

\section{Evolution of the banking market structure}

Table 1 presents the descriptive statistics of the study variables and Table 2 (Appendix) summarizes the evolution of cost efficiency scores and concentration indices for each country over the period 2005-2016. Over the study period, the average Lerner index is 0.443 , while the average HHI stood at 0.301 highlighting the oligopolistic nature of the banking sector with the presence of 26 banking groups mainly from 6 geographical areas which hold $85.7 \%$ of assets and account for $85.6 \%$ of overall net income (BCEAO, 2016). However, the degrees of market concentration depend on the countries (Table 2, Appendix). The banking sector is more competitive in Benin and Togo (Lerner indices 0.439 and 0.45 respectively) compared to Niger (0.619) and Senegal (0.582). The distribution of excess liquidity varies between $3.6 \%$ and $24.6 \%$; the average value is $11.5 \%$.

Table 1. Descriptive statistics

\begin{tabular}{|c|c|c|c|c|c|}
\hline Variables & Observations & Means & Std-errors & Minimum & Maximum \\
\hline EFF_DEA & 722 & 0.833 & 0.139 & 0.386 & 1 \\
\hline EFF_SFA & 722 & 0.791 & 0.075 & 0.548 & 0.988 \\
\hline Lerner & 722 & 0.443 & 0.227 & 0 & 0.882 \\
\hline IHH & 722 & 0.301 & 0.052 & 0.123 & 0.326 \\
\hline EL & 722 & 0.115 & 0.037 & 0.036 & 0.244 \\
\hline Cap & 722 & 0.089 & 0.097 & -0.506 & 0.692 \\
\hline D & 722 & 0.734 & 0.116 & 0.267 & 1.16 \\
\hline Cred & 722 & 0.581 & 0.144 & 0.048 & 1.887 \\
\hline Taille & 722 & 0.143 & 0.100 & 0.004 & 0.463 \\
\hline Growth & 722 & 0.038 & 0.037 & -0.194 & 0.118 \\
\hline INF & 722 & 0.023 & 0.028 & -0.031 & 0.113 \\
\hline
\end{tabular}




\section{Evolution of the banking efficiency}

The average cost efficiency score is $79.1 \%$ over the study period. while in the DEA method it is estimated at $83.3 \%$. On the other hand. a certain disparity is observed on the average cost efficiency levels according to the countries (table 2. appendix). Indeed. the Ivorian. Malian and Nigerian banks recorded the highest cost efficiency scores (nearly $84 \%$ on average). while the lowest performance was recorded in Senegal $(75 \%)$. The results from the DEA method. however. provide a different ranking. The Senegalese and Burkinabe banks recorded the highest cost efficiency scores on average over the study period ( $95.3 \%$ and $95.1 \%$ respectively) and the banks in the other countries were in the range of $80 \%$ to $90 \%$. Togolese and Malian banks had the lowest cost efficiency scores $(85.5 \%$ and $85.1 \%$ respectively). These differences in results between the DEA method and the SFA method are due to the properties of the two approaches. The DEA method. as a non-parametric approach based on mathematical programming, even if it does not require a precise function. its results are very much linked to the variables used. In the absence of some data and the use of proxies in their place. they can be biased (Lapteacru and Lahet. 2014). On the other hand. the stochastic frontier method based on econometric regression can accept proxies. if they are highly correlated with the substituted series. Given the fact that we have used a proxy for the price of labour (w2), we favour the results from the parametric method. Compared with scores obtained in other countries. the level of cost-efficiency of the WAEMU banking sector is high: for example. Cost-efficiency scores are 75\% in Central and Eastern European countries (Lapteacru and Nys. 2011) and 78\% in Latin American banks (Williams. 2012). The high level of cost efficiency scores is certainly related to the decline in operating costs in WAEMU countries. Indeed. the banking sector was quick to introduce into its IT network the changes linked to the new information and communication technologies (NICT) that have marked the international financial environment. The quality of the financial services offered is improving more and more with the development of e-banking services (Internet, telephone) and modern electronic payment terminals (EPTs) to relay certain banking transactions directly. The resulting decrease in personnel costs increases the performance of banks in cost management.

\section{Results of the logistic model}

We first assess the direct effect of the two variables of interest (market concentration and bank liquidity level) on cost efficiency, taking into account the control variables specific to the banking activity and the macroeconomic environment. Finally, we estimate the role of the cross effect (nonlinear relationship).

\subsection{The relationship between efficiency. concentration and bank liquidity}

The results of the different specifications of the relationship between the concentration indicators. efficiency and the excess bank liquidity ratio are presented in Table 3. To compare the results. we perform the analysis by distinguishing the cost efficiency calculated by the SFA method from that obtained by the DEA method. Our results do not suffer from any endogeneity bias since our coefficients are stable under the different approaches. Moreover. the Fisher statistics of the first step are all significant and the Sargan test confirms the validity of the instruments used. Specifically, the concentration indicators (Lerner and HHI) and the excess liquidity ratio retain a negative sign.

These obtained results suggest that an increase in market concentration. i.e, a decrease in competition (increase in Lerner index or HHI index) leads to a decrease in cost efficiency. Our results support the QLH theory (Hicks, 1935) and agree with those of (Eggoh and al., 2021), (Turk Ariss, 
2010), (Delis and Tsionas, 2009) and (Boyd and De Nicolo, 2005) for developing countries. Holding excess liquidity also reduces the cost efficiency of banks.

It is also interesting to observe the effect of control variables on cost efficiency. The GDP growth rate and capitalization do not seem to play a central role in explaining cost efficiency. However, the coefficient on the capitalization variable becomes negative and significant when the HHI is used. On the other hand, size has a positive and significant effect on bank efficiency, but its coefficient becomes negative and significant when using the HHI. The only variables with a robust role in cost efficiency are deposits, loans and inflation. These variables are, moreover, economically significant with negative effects on cost efficiency. Indeed, banks holding more deposits and credits seem to have lowefficiency scores in managing their costs. Also, when inflation is rising, they become less efficient in managing their costs.

Table 3. 2SLS IV estimation of the relationship between efficiency, concentration and excess bank liquidity.

\begin{tabular}{l|ll|ll}
\hline & $(\mathbf{1})$ & $\mathbf{( 2 )}$ & $\mathbf{( 3 )}$ & $\mathbf{( 4 )}$ \\
\cline { 2 - 5 } & DEA'cost-efficiency & \multicolumn{2}{l}{ SFA'cost efficiency } & \\
\hline Variables & Lerner & HHI & Lerner & HHI \\
\hline Lerner & $-0.152^{*}$ & - & $-0.015^{* * *}$ & - \\
& $(0.089)$ & & $(0.006)$ & \\
\hline IHH & - & -0.130 & - & $-0.214^{* *}$ \\
& & $(0.378)$ & & $(0.099)$ \\
\hline Cap & $-0.278^{*}$ & $-0.288^{*}$ & $-0.0195^{* *}$ & $-0.043^{* *}$ \\
& $(0.151)$ & $(0.155)$ & $(0.010)$ & $(0.016)$ \\
\hline D & -0.008 & -0.022 & -0.006 & $-0.012^{* *}$ \\
& $(0.071)$ & $(0.072)$ & $(0.005)$ & $(0.006)$ \\
\hline Cred & $-0.158^{* *}$ & $-0.150^{* *}$ & $-0.029^{* * *}$ & $-0.025^{* * *}$ \\
& $(0.064)$ & $(0.066)$ & $(0.004)$ & $(0.005)$ \\
\hline Taille & -0.016 & -0.0402 & $-0.011^{* * *}$ & $-0.014^{* * *}$ \\
& $(0.054)$ & $(0.052)$ & $(0.003)$ & $(0.003)$ \\
\hline Growth & $0.590^{* * *}$ & $0.441^{* *}$ & -0.013 & $-0.026^{* * *}$ \\
& $(0.206)$ & $(0.188)$ & $(0.010)$ & $(0.009)$ \\
\hline INF & -0.138 & -0.098 & -0.001 & -0.007 \\
& $(0.111)$ & $(0.110$ & $(0.008)$ & $(0.009)$ \\
\hline Constant & $-0.275^{*}$ & $-0.333^{* *}$ & $-0.037^{* * *}$ & $-0.046^{* * *}$ \\
& $(0.150)$ & $(0.148)$ & $(0.011)$ & $(0.011)$ \\
\hline Fisher 1st stage & $1.110^{* * *}$ & $1.040^{* * *}$ & $0.853^{* * *}$ & $0.886^{* * *}$ \\
\hline Sargan Test & $(0.095)$ & $(0.102)$ & $(0.006)$ & $(0.021$ \\
\hline Obs. & $5.29^{* * *}$ & $76.94^{* * *}$ & $8.04 \mathrm{e}+06^{* * *}$ & $3.35^{* * *}$ \\
\hline & 660 & 4.460 & 0.07 & 1.424 \\
\hline
\end{tabular}

Note: $* p<0.05 ; * * p<0.01$; standard errors in parentheses.

\subsection{Estimating the cross effect}

Table 4 summarizes the results of the estimation of the impact of the level of bank liquidity on the QLH. The results show a convergence of the links between the concentration indicators and efficiency. The coefficients of the concentration indicators (Lerner and HHI) have a negative and significant sign except for regression 2 (column 2), while the sign of the cross-effects (Lerner ${ }_{i t} \mathrm{x}$ Excess $50_{\text {it }}$ and HHI $\mathrm{x}$ 
Excess $50_{\text {it }}$ ) is positive and significant. This result shows that the level of excess bank liquidity increases with the QLH. In other words. in the WAEMU, the effects of banking sector concentration on cost efficiency decrease for banks with less excess liquidity. We can explain this result by the harmful role that holding excess liquidity could play on the cost efficiency of banks in the Union. Indeed. holding more excess liquidity leads banks to ration their credits because of the importance of their market power (Khemraj, 2008). This kind of substitution of credits by liquid reserves imposes costs (management cost. opportunity cost) on the banks that hold them because of their low return compared to other assets (Goddard and al., 2004; Molyneux and Thornton, 1992). Partial or total recycling of this excess liquidity to the financing of the economy would reduce the burden on these banks and. in turn. improve their efficiency in managing their costs.

Table 4. Estimation of the impact of excess liquidity on the relationship between market concentration and efficiency using the 2SLS IV method

\begin{tabular}{|c|c|c|c|c|}
\hline \multirow{3}{*}{ Variables } & (1) & (2) & (3) & (4) \\
\hline & \multicolumn{2}{|c|}{ DEA'cost-efficiency } & \multicolumn{2}{|c|}{ SFA'cost efficiency } \\
\hline & Lerner & $\mathrm{HHI}$ & Lerner & $\mathrm{HHI}$ \\
\hline Lerner & $\begin{array}{l}-0.842 * * \\
(0.394)\end{array}$ & & $\begin{array}{l}-0.016 * * * \\
(0.006)\end{array}$ & \\
\hline Effects $_{a}$ & $-0.776^{* *}$ & - & $-0.014 * *$ & $-0.210 * * *$ \\
\hline $\mathrm{IHH}$ & - & $\begin{array}{l}-1.087 \\
(0.770)\end{array}$ & - & $\begin{array}{l}-0.225 * * \\
(0.103)\end{array}$ \\
\hline IHH x Excess50 & - & $\begin{array}{c}0.215^{*} \\
(0.116)\end{array}$ & - & $\begin{array}{c}0.0154 * * * \\
(0.006)\end{array}$ \\
\hline Cap & $\begin{array}{l}0.134 \\
(0.125)\end{array}$ & $\begin{array}{l}0.144 * \\
(0.0808)\end{array}$ & $\begin{array}{l}-0.005 \\
(0.005)\end{array}$ & $\begin{array}{l}-0.0107 * \\
(0.00550)\end{array}$ \\
\hline $\mathrm{D}$ & $\begin{array}{l}-0.292 * * * \\
(0.097)\end{array}$ & $\begin{array}{l}-0.131 * * \\
(0.065)\end{array}$ & $\begin{array}{l}-0.0291 * * * \\
(0.004)\end{array}$ & $\begin{array}{l}-0.025^{* * *} \\
(0.005)\end{array}$ \\
\hline Cred & $\begin{array}{l}0.050 \\
(0.059)\end{array}$ & $\begin{array}{l}0.0283 \\
(0.0490)\end{array}$ & $\begin{array}{l}-0.0106 * * * \\
(0.0025)\end{array}$ & $\begin{array}{l}-0.0141 * * * \\
(0.00281)\end{array}$ \\
\hline Taille & $\begin{array}{l}1.187 * * * \\
(0.394)\end{array}$ & $\begin{array}{l}0.477 * * \\
(0.149)\end{array}$ & $\begin{array}{l}-0.0138 \\
(0.010)\end{array}$ & $\begin{array}{l}-0.0259 * * * \\
(0.009)\end{array}$ \\
\hline Growth & $\begin{array}{l}-0.153 \\
(0.176)\end{array}$ & $\begin{array}{l}0.0189 \\
(0.177)\end{array}$ & $\begin{array}{l}0.000808 \\
(0.008)\end{array}$ & $\begin{array}{l}0.0128 \\
(0.010)\end{array}$ \\
\hline INF & $\begin{array}{l}0.089 \\
(0.269)\end{array}$ & $\begin{array}{l}-0.195 \\
(0.241)\end{array}$ & $\begin{array}{l}-0.0320 * * * \\
(0.011)\end{array}$ & $\begin{array}{l}-0.0320 * * * \\
(0.011)\end{array}$ \\
\hline Constant & $\begin{array}{l}1.586^{* * *} \\
(0.289)\end{array}$ & $\begin{array}{l}1.092 * * * \\
(0.131)\end{array}$ & $0.850 * * *(0.006)$ & $\begin{array}{c}0.881 * * * \\
(0.0201)\end{array}$ \\
\hline Fisher 1st stage & $7.84 * * *$ & $146^{* * *}$ & $16.26^{* * * *}$ & $7.34 * * *$ \\
\hline Sargan Test & 2.143 & 0.001 & 0.013 & 1.505 \\
\hline Obs. & 660 & 660 & 660 & 660 \\
\hline
\end{tabular}

Note: $* \mathrm{p}<0.10 ; * * \mathrm{p}<0.05 ; * * * \mathrm{p}<0.01$; errors in parentheses. a the effects (differences between the two coefficients) are calculated by us. 


\section{Conclusion}

The objective of this paper was to assess the impact of bank liquidity level on the relationship between bank concentration and efficiency. Using a sample of 60 banks from 7 WAEMU countries in the period 2005-2016. The results obtained suggest that market concentration and excess bank liquidity have a negative influence on cost efficiency. In other words, banks with higher market power (or excess liquidity) are also less efficient in managing their costs. This result supports the Quiet Life Hypothesis, which suggests that in a situation of limited competition. managers adopt sub-optimal behaviour that is detrimental to bank profitability. However, the effects of banking industry concentration on cost efficiency decrease for banks with less excess liquidity. This result shows that holding excess liquidity increases the effects of QLH.

This study has implications for monetary policy and banking regulation. Monetary authorities need to address the oligopolistic situation in the banking sector to encourage banks to recycle excess liquidity. This could be achieved by promoting competition in the banking sector and encouraging financial innovation by banks. The second implication is the control of operating costs that only reduce the cost efficiency of banks. To this end. the WAEMU banking sector must further integrate NICs into its IT network to encourage banks to develop e-banking services (Internet. telephone) and modern electronic payment terminals (EPTs) to directly relay certain banking transactions. The WAEMU' banks could also think about further developing mobile banking in their networks. This would be a major innovation that could help reduce the operating costs that weigh on the efficiency of banks.

\section{REFERENCES}

[1] AMIDU, M. (2011). Banking market structure and bank intermediation strategies in emerging markets: Three essays. PhD thesis, Faculty of business a law School of Mathe nagementnd University of Southampton. Royaume-Uni.

[2] BAIN, J. S. (1956) Barriers to New Competition. Cambridge: Harvard Press.

[3] BATTESE, G. ET COELLI, T. (1995). A model for technical inefficiency effects in a stochastic frontier production function for panel data. Empirical economics, Vol. 20, №2, 325-332.

[4] BERGER, A. ET HANNAN, T. (1998). The efficiency cost of market power in the banking industry: A test of the "quiet life" and related hypotheses. Review of Economics and Statistics, Vol. 80, N³, 454-465.

[5] BOYD, J.H., DE NICOLO, G. (2005). The Theory of Bank Risk Taking and Competition Revisited. Journal of Finance, Vol. 60, $\mathrm{N}^{\circ} 3,1329-1343$.

[6] CHARNES A., COOPER W.W. ET RHODES E. (1978). Measuring the efficiency of decision-making units, European Journal of Operational Research, Vol. 2, $\mathrm{N}^{\circ} 6,429-444$.

[7] CHIRWA, E. W. (2003). Determinants of commercial bank's profitability in Malawi: A co-integration approach. Applied Financial Economics, Vol. 13, No $8,565-571$.

[8] DANNON, H., BANGAKE, C. et EGGOH, J. (2019). Structure de marché et performance économique des institutions de microfinance dans l'UEMOA : cas du Bénin et du Togo. Revue Mondes en développement, Vol. 1, $\mathrm{N}^{\circ} 185,29-44$.

[9] DEGRYSE, H. ET ONGENA, S. (2007). The impact of competition on bank orientation. Journal of Financial Intermediation, Vol. $16, N^{\circ} 3,399-424$.

[10] DELIS, M., TSIONAS, E., (2009). The joint estimation of bank-level market power and efficiency. Journal of Banking and Finance, Vol.33, 1842-1850.

[11] DELL'ARICCIA, G. ET MARQUEZ, R. (2004). Information and bank credit allocation. Journal of financial Economics, Vol. 72 , $\mathrm{N}^{\circ} 1,185-214$.

[12] DEMIRGUC-KUNT, A. ET HUIZINGA, H. (1999). Market discipline and financial safety net design, Policy Research Working Paper Series 2183, The World Bank. 
[13] DIETSCH M. ET LOZANO, V. A. (2000) How the environment determines banking efficiency: A comparison between French and Spanish industries, Journal of Banking and Finance, Vol. 24, $\mathrm{N}^{\circ} 6,985-1004$.

[14] DIETSCH, M. (1992). Quel modèle de concurrence dans l'industrie bancaire ? Revue Économique, Vol. 43, №2, 229-260.

[15] Eggoh J., Dannon P. H., Ndiaye A. (2021). « Analysis of the Quiet Life Hypothesis Implications in the WAEMU Banking Sector » (Avec J. Eggoh et P. Dannon), African Development Review, Vol. 33, Issue 3, p. 533-545.

[16] https://doi.org/10.1111/1467-8268.12586

[17] FlAMini, V., MCDONALD, C. A. ET SCHUMACHER, L. B. (2009). The Determinants of Commercial Bank Profitability in Sub-Saharan Africa. IMF Working Papers, 1-30.

[18] FRIES S. ET TACI A., (2005). Cost efficiency of banks in transition: Evidence from 289 banks in 15 post-communist countries. Journal of Banking and Finance 29, $\mathrm{N}^{\circ} 1,55-81$.

[19] FUNGÁČOVÁ, Z., SOLANKO, L., ET WEILL, L. (2014). Does competition influence the bank lending channel in the Euro area? Journal of Banking and Finance, Vol. 31, 296-314.

[20] GILBERT, R. A. (1984). Bank market structure and competition: A survey, Journal of Money, Credit and Banking, Vol. 16, N4, 617-644.

[21] GILBERT, R. A. ET ZARETSKY, A. M. (2003). Banking antitrust: Are the assumptions still valid? Federal Reserve Bank of Saint Louis Review, Vol. 85, Nº, 29-52.

[22] GODDARD, J., MOLYNEUX, P. ET WILSON, J. (2004). The profitability of European banks: a cross-sectional and dynamic panel analysis. The Manchester School, Vol. 72, N³, 363-381.

[23] GRIGORIAN ET MANOLE (2002). Determinants of commercial bank performance in transition: an application of data Envelopment analysis, IMF Working Paper WP/02/146.

[24] GUNJI, H. ET YUAN, Y., (2010). Bank profitability and the bank lending channel: evidence from China. Journal of Asian Economics, Vol. 21, $\mathrm{N}^{\circ} 2,129-144$.

[25] HANNAN, T. H. (1991). Foundations of the structure-conduct-performance paradigm in banking. Journal of Money. Credit and Banking, Vol. 23, $\mathrm{N}^{\circ} 1,68-84$.

[26] HERMALIN, B. (1992). The effects of competition on executive behavior. The Rand Journal of Economics, Vol. 23, № 3, 350365.

[27] HICKS, J. (1935) Annual survey of economic theory: The theory of monopoly. Econometrica, Vol. 3, 1-20.

[28] JONDROW, J., LOVELL, C.A.K, MATEROV, I.S. ET SCHMIDT, P, (1982). On the estimation of technical inefficiency in the stochastic frontier production function model. Journal of Econometrics, North-Holland Publishing Company, Vol. 19, №1982, 233238.

[29] JOSEPH, A. (2002). La réforme du secteur financier en Afrique, Document technique du Centre de développement de l'OCDE, OCDE, Paris.

[30] KABLAN, S., (2009b). Mesure de la performance des banques dans les pays en voie de développement : le cas de l'UEMOA, African Development Review, Vol. 21, №2, 367-399.

[31] KABLAN, S. (2009a). Banking efficiency and financial development in sub-Saharan Africa. The African Finance Journal, Vol. 21, $\mathrm{N}^{\circ} 2,1-26$.

[32] KHEMRAJ, T. (2008). Excess liquidity, oligopolistic loan markets and monetary policy in LDCs. DESA Working Paper No. 64 ST/ESA/2008/DWP/64 UN/DESA Working Papers.

[33] KIRKPATRICK, C., MURINDE, V. ET TEFULA, M. (2008). The Measurement and Determinants of X-efficiency in Commercial banks in Sub-Saharan Africa, The European Journal of Finance, Vol. 14, Nº , 625-39.

[34] KOETTER, M., KOLARI, J., SPIERDIJK, J., (2012). Enjoying the quiet life under deregulation? Evidence from adjusted Lerner indices for U.S. banks. Review of Economics and Statistics, Vol. 94, ํ2, 462-480.

[35] LAPTEACRU, I. ET LAHET, D. (2014) Efficience et pouvoir de marché des banques en Thaïlande suite aux crises financières. Revue Économique, vol. 65, N5, 675-698.

[36] LAPTEACRU, I. ET NYS, E. (2011). L'impact de la concurrence sur l'efficience des banques: Le cas des PECO. Revue Économique, Vol. 62, N², 313-330.

[37] LÉON, F. (2012). Effet de la concurrence sur l'efficience bancaire en Afrique : Le cas de l'UEMOA. Études et Document de Travail $\mathrm{N}^{\circ}$ 2012.2. CERDI.

[38] MAUDOS, J. ET DE GUEVARA, J. (2007). The cost of market power in banking: Social welfare loss vs. cost inefficiency. Journal of Banking \& Finance, Vol. 31, ํ7, 2103-2125. 
[39] MOLYNEUX, P. ET THORNTON, J. (1992). Determinants of European bank profitability: a note. Journal of Banking and Finance Vol. 16, 1173-1178.

[40] NDIAYE, G. S. (2008). Institutions financières et développement économique. Thèse non publiée de Doctorat en sciences économiques, Université d'Auvergne, Clermont-Ferrand 1, CERDI. France.

[41] NGUYEN, V. H. T. ET BOATENG, A., (2013). The impact of excess reserves beyond precautionary levels on Bank Lending Channels in China. Journal of International Financial Markets, Institutions and Money, Vol. 26, N²013, 358-377.

[42] NUBUKPO, K (2007b). Politique monétaire et servitude volontaire : la gestion du Franc CFA par la BCEAO. Politique africaine $\mathrm{N}^{\circ} 105$, Karthala, Paris, mars 2007.

[43] OKEAHALAM, C. C. (2002b.). Concentration in the banking sector of the common monetary area of Southern Africa. In Conference on Development Issues in the New Economy. University of Cape Town, Cape Town.

[44] OKEAHALAM, C. (2002a). Structure and conduct in the commercial banking sector of South Africa. Trade and Industrial Policy Strategies.

[45] OKEAHALAM, C. (1998). An analysis of the price-concentration relationship in the Botswana commercial banking industry. Journal of African Finance and Economic Development, Vol. 3, 65-84.

[46] OUÉDRAOGO, S. (2012). Concentration bancaire, profitabilité et développement financier bancaires dans l'UEMOA. Revue Économique et Monétaire, BCEAO, $\mathrm{N}^{\circ} 12$ - Décembre 2012, 45-76

[47] OUÉDRAOGO, S. (2011). "Banque et transmission monétaire dans l'UEMOA : effets des bilans bancaires, de la concentration bancaire et de l'excès de liquidité bancaire sur l'efficacité de la politique monétaire de la BCEAO. Thèse non publiée de doctorat en sciences économiques, CERDI/Université d'Auvergne, 2011.

[48] PRESBITERO, A. F. ET ZAZZARO, A. (2011). Competition and relationship lending: Friends or foes? Journal of Financial Intermediation, Vol. 20, №3, 387-413.

[49] RYAN, R., M., O’TOOLE, C., M., MCCANN, F., (2014). Does bank market power affect SME financing constraints? Journal of Banking and Finance, Vol. 49, $\mathrm{N}^{\circ}$ 2014, 495-505.

[50] SELTEN, R. (1986.) Elementary theory of slack-ridden imperfect competition. In New developments in the analysis of market structure. Proceedings of a conference held by the International Economic Association in Ottawa, page 126. The MIT Press. Canada.

[51] TURK ARISS, R. (2010). On the implications of market power in banking: Evidence from developing countries. Journal of Banking and Finance, Vol. 34, N4, 765-775.

[52] YANG, J. ET SHAO, S. (2016). Impact of bank competition on the bank lending channel of monetary transmission: Evidence from China. International Review of Economics and Finance, Vol. 43, 468-481 


\section{Appendix}

Table 2. Evolution of cost efficiency scores and concentration indexes for each country from 2005 to 2016

\begin{tabular}{|c|c|c|c|c|c|c|c|c|c|c|c|c|}
\hline & 2005 & 2006 & 2007 & 2008 & 2009 & 2010 & 2011 & 2012 & 2013 & 2014 & 2015 & 2016 \\
\hline \multicolumn{13}{|c|}{ Cost efficiency (SFA) } \\
\hline Benin & 0.772 & 0.774 & 0.776 & 0.779 & 0.78 & 0.783 & 0.785 & 0.787 & 0.789 & 0.791 & 0.793 & 0.795 \\
\hline Burkina & 0.767 & 0.769 & 0.772 & 0.774 & 0.776 & 0.779 & 0.781 & 0.783 & 0.785 & 0.787 & 0.79 & 0.792 \\
\hline Ivory Coast & 0.828 & 0.83 & 0.831 & 0.833 & 0.835 & 0.837 & 0.838 & 0.84 & 0.842 & 0.843 & 0.845 & 0.847 \\
\hline Mali & 0.828 & 0.829 & 0.831 & 0.833 & 0.835 & 0.836 & 0.838 & 0.84 & 0.841 & 0.843 & 0.845 & 0.846 \\
\hline Niger & 0.828 & 0.829 & 0.831 & 0.833 & 0.835 & 0.836 & 0.838 & 0.84 & 0.841 & 0.843 & 0.845 & 0.847 \\
\hline Senegal & 0.733 & 0.736 & 0.738 & 0.741 & 0.744 & 0.746 & 0.748 & 0.751 & 0.754 & 0.756 & 0.759 & 0.761 \\
\hline Togo & 0.763 & 0.766 & 0.768 & 0.771 & 0.773 & 0.775 & 0.777 & 0.78 & 0.782 & 0.784 & 0.786 & 0.789 \\
\hline \multicolumn{13}{|c|}{ Cost efficiency (DEA) } \\
\hline Benin & 0.855 & 0.871 & 0.85 & 0.941 & 0.911 & 0.938 & 0.925 & 0.944 & 0.941 & 0.891 & 0.851 & 0.872 \\
\hline Burkina & 0.975 & 0.951 & 0.944 & 0.932 & 0.996 & 0.839 & 0.909 & 0.96 & 0.971 & 0.974 & 0.991 & 0.975 \\
\hline Ivory Coast & 0.832 & 0.837 & 0.848 & 0.878 & 0.865 & 0.887 & 0.902 & 0.882 & 0.842 & 0.818 & 0.913 & 0.913 \\
\hline Mali & 0.824 & 0.861 & 0.879 & 0.839 & 0.827 & 0.81 & 0.831 & 0.886 & 0.907 & 0.875 & 0.879 & 0.851 \\
\hline Niger & 0.937 & 0.828 & 0.885 & 0.873 & 0.861 & 0.811 & 0.804 & 0.84 & 0.878 & 0.896 & 0.88 & 0.902 \\
\hline Senegal & 0.927 & 0.951 & 0.951 & 0.892 & 0.946 & 0.934 & 0.964 & 0.947 & 0.971 & 0.961 & 0.998 & 0.99 \\
\hline Togo & 0.855 & 0.897 & 0.883 & 0.905 & 0.906 & 0.925 & 0.953 & 0.933 & 0.931 & 0.925 & 0.892 & 0.254 \\
\hline \multicolumn{13}{|c|}{ Herfindahl-Hirschmann Index (HHI) } \\
\hline Benin & 0.229 & 0.213 & 0.202 & 0.268 & 0.25 & 0.262 & 0.265 & 0.247 & 0.252 & 0.247 & 0.235 & 0.236 \\
\hline Burkina & 0.225 & 0.218 & 0.216 & 0.212 & 0.207 & 0.202 & 0.226 & 0.23 & 0.25 & 0.242 & 0.246 & 0.252 \\
\hline Ivory Coast & 0.136 & 0.134 & 0.134 & 0.134 & 0.129 & 0.125 & 0.130 & 0.126 & 0.125 & 0.125 & 0.123 & 0.125 \\
\hline Mali & 0.192 & 0.184 & 0.188 & 0.178 & 0.17 & 0.16 & 0.152 & 0.149 & 0.147 & 0.149 & 0.143 & 0.147 \\
\hline Niger & 0.218 & 0.22 & 0.22 & 0.217 & 0.226 & 0.226 & 0.227 & 0.229 & 0.227 & 0.226 & 0.227 & 0.231 \\
\hline Senegal & 0.262 & 0.258 & 0.249 & 0.252 & 0.24 & 0.248 & 0.238 & 0.22 & 0.204 & 0.201 & 0.202 & 0.191 \\
\hline Togo & 0.247 & 0.252 & 0.254 & 0.253 & 0.256 & 0.269 & 0.268 & 0.266 & 0.278 & 0.29 & 0.321 & 0.326 \\
\hline \multicolumn{13}{|c|}{ Lerner Index } \\
\hline Benin & 0.47 & 0.479 & 0.456 & 0.475 & 0.479 & 0.46 & 0.485 & 0.474 & 0.396 & 0.359 & 0.321 & 0.415 \\
\hline Burkina & 0.575 & 0.574 & 0.57 & 0.502 & 0.49 & 0.546 & 0.565 & 0.511 & 0.509 & 0.546 & 0.531 & 0.569 \\
\hline Ivory Coast & 0.497 & 0.533 & 0.533 & 0.535 & 0.556 & 0.598 & 0.581 & 0.567 & 0.512 & 0.572 & 0.56 & 0.598 \\
\hline Mali & 0.634 & 0.629 & 0.586 & 0.584 & 0.568 & 0.555 & 0.436 & 0.382 & 0.44 & 0.565 & 0.574 & 0.596 \\
\hline Niger & 0.589 & 0.635 & 0.628 & 0.669 & 0.607 & 0.652 & 0.688 & 0.684 & 0.647 & 0.576 & 0.614 & 0.437 \\
\hline Senegal & 0.536 & 0.629 & 0.538 & 0.528 & 0.557 & 0.585 & 0.599 & 0.598 & 0.679 & 0.567 & 0.583 & 0.584 \\
\hline Togo & 0.337 & 0.514 & 0.519 & 0.431 & 0.491 & 0.345 & 0.49 & 0.337 & 0.407 & 0.505 & 0.486 & 0.532 \\
\hline
\end{tabular}

